\title{
GAMBARAN PENGETAHUAN MAHASISWA KEPERAWATAN TENTANG PENULARAN INFEKSI NOSOKOMIAL DI RUMAH SAKIT PTPN II BANGKATAN BINJAI TAHUN 2017
}

\author{
Description of Nursing Student Knowledge About Transmission of Nosocomial \\ Infections in PTPN II Bangkatan Binjai Hospital 2017
}

\author{
Ilham Syahputra Siregar ${ }^{1}$ \\ ${ }^{1}$ Dosen Akademi Keperawatan Sehat Binjai \\ E-mail: ilhamsyahputra0219@gmail.com
}

\begin{abstract}
Abstrak
Infeksi Nosokomial adalah infeksi yang muncul selama seseorang tersebut dirawat dirumah sakit dan mulai menunjukan suatu gejala selama seseorang itu dirawat atau setelah selesai dirawat dan menunjukkan gejala setelah 72 jam pasien berada dirumah sakit. Infeksi ini menyebabkan 1,4 juta kematian setiap hari diseluruh dunia (WHO, 2015). Di Indonesia angka prevalensi infeksi nosokomial cukup tinggi yaitu $6 \%$ - $16 \%$ dengan rata-rata $9,8 \%$ infeksi nosokomial yang terjadi diakibatkan karena infeksi luka operasi (ILO). Berdasarkan survei yang peneliti lakukan, insiden infeksi nosokomial menunjukkan angka prevalensi sekitar 1,5\% kasus yang terjadi di Rumah Sakit PTPN II Bangkatan Binjai. Tujuan penelitian ini adalah untuk mengetahui gambaran pengetahuan Mahasiswa Keperawatan tentang penularan infeksi nosokomial di Rumah Sakit PTPN II Bangkatan Binjai tahun 2017. Tujuan khusus dalam penelitian ini adalah untuk mengidentifikasi gambaran pengetahuan Mahasiswa Keperawatan tentang penularan infeksi nosokomial secara kontak langsung, melalui common vehicle, melalui udara dan inhalasi, atau melalui vektor di Rumah Sakit PTPN II Bangkatan Binjai Tahun 2017. Dengan alasan tersedianya jumlah sampel yang diharapkan peneliti dan untuk efisiensi waktu dan biaya. Berasarkan hasil penelitian yang telah dilakukan peneliti maka dapat diketahui bahwa Gambaran tingkat pengetahuan mahasiswa keperawatan tentang penularan infeksi nosokomial di rumah sakit PTPN II Bangkatan Binjai mayoritas berpengetahuan baik berdasarkan penularan secara kontak langsung sebanyak 15 orang $(75 \%)$, melalui common vehicle sebanyak 10 orang $(50 \%)$, penularan melalui udara dan inhalasi sebanyak 14 orang $(70 \%)$ dan penularan melalui vektor sebanyak 14 orang (70\%). Saran bagi pihak rumah sakit dan tenaga kesehatan hendaknya dapat meningkatkan mutu kesehatan dengan membuat surveilans kesehatan yang lebih baik untuk menurunkan angka infeksi nosokomial.
\end{abstract}

Kata kunci : Gambaran Pengetahuan, Infeksi Nosokomial

\begin{abstract}
Nosocomial infection is an infection that appears as long as a person is hospitalized and begins to show a symptom as long as someone is being treated or after being treated and showing symptoms after 72 hours the patient is in the hospital. Infeki nosocomial is still the main cause of high morbidity and mortality in the world. This infection causes 1.4 million deaths every day around the world (WHO, 2015). In Indonesia the prevalence of nosocomial infections is quite high at $6 \%-16 \%$ with an average of $9.8 \%$ of nosocomial infections that occur due to surgical wound infections (ILO). Based on the survey that the researchers did, the incidence of nosocomial infections showed a prevalence rate of around $1.5 \%$ of cases that occurred at PT Departure II Bangkat Binjai Hospital. The purpose of this study was to find out the description of Nursing Students 'knowledge about the transmission of nosocomial infections in PTPN II Hospital Binjai Departure in 2017. The specific objective of this study was to identify nursing students' knowledge about contacting nosocomial infections directly, through common vehicle, by air and inhalation, or through vectors at PTPN II Hospital Binjai Departure in 2017. The reason is the availability of samples expected by researchers and for time and cost efficiency. Based on the results of research conducted by the researcher, it can be seen that the description of the level of knowledge of nursing students about the transmission of nosocomial infections in PTPN II Bangkat Binjai hospital is mostly well-informed based on direct contact transmission of 15 people $(75 \%)$, through common vehicles of 10 people ( $50 \%$ ), airborne and inhalation transmission as many as 14 people $(70 \%)$ and vector-borne transmission as many as 14 people (70\%). Suggestions for hospitals and health workers should be able to improve the quality of health by making better health surveillance to reduce the number of nosocomial infections.
\end{abstract}

Keywords: Knowledge Overview, Nosocomial Infection 


\section{PENDAHULUAN}

Di Indonesia Rumah Sakit sebagai salah satu bagian sistem pelayanan kesehatan secara garis besar memberikan pelayanan untuk masyarakat berupa pelayanan kesehatan mencakup pelayan medik, pelayanan penunjang medik, rehabilitasi, dan pelayanan perawatan. Pelayanan tersebut dilaksanakan melalui unit gawat darurat, unit rawat jalan, dan unit rawat inap (Herlambang dkk, 2014).

Perkembangan Rumah Sakit awalnya hanya memberi pelayanan yang bersifat penyembuhan (kuratif) terhadap pasien namun, karena kemajuan ilmu pengetahuan pelayanan kesehatan di Rumah Sakit berkembang menjadi upaya pemulihan (rehabilitatif), promosi kesehatan (promotif), dan pencegahan (preventif) secara terpadu (Arita, 2014). Rumah Sakit merupakan sarana upaya kesehatan yang menyelenggarakan kegiatan pelayanan kesehatan dan merupakan institusi penyedia jasa (Pratama, 2017).

Mutu pelayanan medis dan kesehatan di Rumah Sakit sangat erat kaitannya dengan manajemen Rumah Sakit (quality of services) dan keprofesionalan kinerja Rumah Sakit (quality of care). Dalam pemberian pelayanan kesehatan sebuah lembaga Rumah Sakit mempunyai kebijakan dalam penanganan kendala di dalamnya. Dalam hal pelayanan Medis, Rumah Sakit menekankan fungsi utama dimana seorang penderita suatu penyakit keluar dari Rumah Sakit akan menjadi sehat bukan sebaliknya (Herlambang dkk, 2014).

Dalam hal keperawatan peran seorang tenaga keperawatan sangat penting dalam rangka proses penyembuhan seorang pasien dimana seorang perawat harus mampu melindungi pasien dalam hal pengendalian infeksi dan penularan penyakit menular. Dalam pemberian asuhan keperawatan, penerapan manajemen keperawatan sangat dibutuhkan karena proses pemberian pelayanan kesehatan diberikan perawat kepada individu, keluarga, keluarga, dan masyarakat secara profesional secara bio-psiko-sosial dan spiritual (Herlambang dkk, 2014).

Pembahasan mengenai Rumah Sakit tidak terlepas dari penyebaran penyakit infeksi. Penyakit infeksi adalah penyakit yang disebabkan oleh mikroba patogen dan bersifat sangat dinamis. Secara umum proses terjadinya infeksi penyakit melibatkan 3 (tiga) faktor yang saling berinteraksi yaitu faktor penyebab penyakit yang sering disebut agen, faktor manusia yang sering disebut pejamu (host), dan faktor lingkungan.

Infeksi nosokomial dapat disebabkan oleh mikroorganisme yang didapat dari orang lain (cross infection) atau disebabkan oleh flora normal dari pasien itu sendiri (endogenous infection). Kebanyakan infeksi yang terjadi di Rumah Sakit disebabkan faktor eksternal, yaitu penyakit yang penyebarannya melalui makanan, udara, dan benda yang tidak steril.

Mekanisme transmisi mikroba patogen ke pejamu yang rentan melalui dua cara yaitu transmisi langsung dan transmisi tidak langsung. Transmisi langsung merupakan penularan langsung oleh mikroba patogen ke pintu masuk yang sesuai dari pejamu, sebagai contoh adanya sentuhan, gigitan, ciuman, atau saat melakukan transfusi darah ada darah yang terkontaminasi mikroba patogen sedangkan, Transmisi tidak langsung adanya penularan mikroba patogen yang memerlukan adanya media perantara baik berupa barang/bahan, air, makanan/minuman, maupun vektor (Septriari, 2015).

Faktor-faktor yang terlibat dalam infeksi nosokomial pada dasarnya bergantung pada mikroorganisme, tuan rumah (pasien dan staff), lingkungan, dan pengobatan. Kemungkinan terjadinya infeksi bergantung pada karakteristik mikroorganisme, ke-resistensian terhadap zat-zat antibiotika, tingkat virulensi, dan banyaknya bakteri infeksius.

Infeksi nosokomial dapat memberikan dampak seperti menyebabkan cacat fungsional, stress emosional, dan dapat menyebabkan cacat yang permanen serta kematian. Selain itu, di negara berkembang prevalensi HIV/AIDS semakin tinggi, meningkatkan biaya kesehatan di berbagai negara yang tidak mampu dengan meningkatkan lama perawatan di rumah sakit, morbiditas dan mortalitas semakin 
tinggi, adanya tuntutan secara hukum, dan penurunan citra rumah sakit.

Infeki nosokomial masih merupakan penyebab utama tingginya angka kesakitan dan kematian di dunia. Infeksi ini menyebabkan 1,4 juta kematian setiap hari diseluruh dunia. Kejadian infeksi nosokomial di negara berkembang jauh lebih tinggi, terutama infeksi yang umumnya dapat dicegah (misalnya, infeksi seksio sesarea) (Septriari, 2015).

Angka infeksi nosokomial di beberapa Negara berkisar antara 3,3\% $9,2 \%$ yang artinya beberapa persen penderita yang dirawat di Rumah Sakit tertular infeksi nosokomial dan dapat terjadi secara akut atau secara kronis. Berdasarkan survei dikawasan Asia, di wilayah Asia Tenggara $11,8 \%$ pasien di Rumah Sakit terkena infeksi nosokomial. Prevalensi infeksi nosokomial tertinggi terjadi di ruang ICU, ruang bedah $(\mathrm{OK})$, dan ruang bangsal.

Di Indonesia angka prevalensi infeksi nosokomial cukup tinggi yaitu 6\% $16 \%$ dengan rata-rata $9,8 \%$ infeksi nosokomial yang terjadi diakibatkan karena infeksi luka operasi (ILO). Di wilayah Sumatera utara angka prevalensi kejadian infeksi nosokomial sebanyak 5,6\% kasus. (http://repository.usu.ac.id)

Berdasarkan survei yang peneliti lakukan, insiden infeksi nosokomial menunjukkan angka prevalensi sekitar 1,5\%

HASIL PENELITIAN

Tabel 4.1 Distribusi Karakteristik Responden Mengenai Gambaran Pengetahuan Mahasiswa Keperawatan Tentang Penularan Infeksi Nosokomial Berdasarkan Umur Di Rumah Sakit PTPN II Bangkatan Binjai Tahun 2017

\begin{tabular}{|c|c|c|c|}
\hline No & Umur & Junlah & Persentase (\%) \\
\hline 1. & $18-20$ Tahun & 10 & $50 \%$ \\
\hline 2. & $21-22$ Tahun & 6 & $30 \%$ \\
\hline 3. & $23-24$ Tahun & 3 & $15 \%$ \\
\hline 4. & $25-26$ Tahun & 1 & $5 \%$ \\
\hline \multicolumn{2}{|r|}{ Total } & 20 & $100 \%$ \\
\hline
\end{tabular}

Analisa Data :

Dari tabel 4.1 diatas dapat dilihat bahwa sampel penelitian yang berada dalam kelompok umur 18-20 tahun sebanyak 10 Bangkatan Binjai.

Berdasarkan data-data diatas penulis merasa tertarik dan ingin mengetahui Gambaran Pengetahuan Mahasiswa Keperawatan tentang penularan Infeksi Nosokomial di Rumah Sakit PTPN II Bangkatan Binjai tahun 2017.

\section{METODE}

Jenis penelitian yang digunakan adalah Jenis penelitian yang digunakan adalah Deskriptif korelasional dengan pendekatan Cross sectional.

Penelitian dilaksanakan di Rumah Sakit PTPN II Bangkatan Binjai.

Waktu penelitian berlangsung dari bulan Maret sampai bulan Mei 2017.

Dalam penelitian ini populasi adalah semua mahasiswa keperawatan yang ada di Rumah Sakit PTPN II Bangkatan Binjai pada tahun 2017 yaitu berjumlah 20 orang.

Sampel yang diambil peneliti adalah Mahasiswa keperawatan yang ada di Rumah Sakit PTPN II Bangkatan Binjai tahun 2017. Sampel pada penelitian ini sebanyak 20 orang.

Pada penelitian ini digunakan teknik Total Sampling yaitu pengambilan sample dengan cara mengambil semua anggota populasi menjadi sample, yaitu 20 orang. kasus yang terjadi di Rumah Sakit PTPN II

orang (50\%), umur 21-22 tahun sebanyak 6 orang (30\%), umur 23-24 tahun sebanyak 3 orang $(15 \%)$, dan umur 25-26 tahun sebanyak 1 orang $(5 \%)$. 
Tabel 4.2 Distribusi Karakteristik Responden Mengenai Gambaran Pengetahuan Mahasiswa Keperawatan Tentang Penularan Infeksi Nosokomial Berdasarkan Jenis Kelamin Di Rumah Sakit PTPN II Bangkatan Binjai Tahun 2017

\begin{tabular}{|c|c|c|c|}
\hline No & Jenis Kelamin & Jumlah & Presentase (\%) \\
\hline 1. & Laki-Laki & 8 & 40 \\
\hline 2. & Perempuan & 12 & 60 \\
\hline \multicolumn{2}{|r|}{ Total } & 20 & $100 \%$ \\
\hline
\end{tabular}

Analisa Data:

dan berjenis kelamin perempuan sebanyak

Dari tabel 4.2 diatas dapat dilihat bahwa

12 orang $(60 \%)$.

sampel penelitian berdasarkan jenis

kelamin laki-laki sebanyak 8 orang $(40 \%)$

Tabel 4.3 Distribusi Karakteristik Responden Mengenai Gambaran Pengetahuan Mahasiswa Keperawatan Tentang Penularan Infeksi Nosokomial Berdasarkan Tingkat Pendidikan Di Rumah Sakit PTPN II Bangkatan Binjai Tahun 2017

\begin{tabular}{c|c|c|c}
\hline No & Program Pendidikan & Jumlah & Presentase (\%) \\
\hline 1. & D III & 20 & 100 \\
\hline \multicolumn{2}{r|}{ Total } & $\mathbf{2 0}$ & $\mathbf{1 0 0 \%}$ \\
\hline
\end{tabular}

Dari tabel 4.3 diatas dapat dilihat bahwa sampel penelitian dengan tingkat pendidikan D-II sebanyak 20 orang $(100 \%)$.

Berikut ini merupakan hasil pengukuran quisioner responden tentang Gambaran Pengetahuan Mahasiswa Keperawatan Tentang Penularan Infeksi
Nosokomial di Rumah Sakit PTPN II Bangkatan Binjai Tahun 2017 dalam hal penularan infeksi nosokomial secara kontak langsung, melalui common vehicle, melalui udara dan inhalasi, serta melalui perantara vektor.

Tabel 4.4 Distribusi Frekuensi Mengenai Gambaran Pengetahuan Mahasiswa Keperawatan Tentang Penularan Infeksi Nosokomial Berdasarkan Penularan Infeksi Secara Kontak Langsung Di Rumah Sakit PTPN II Bangkatan Binjai Tahun 2017

\begin{tabular}{|c|c|c|c|}
\hline No & Kategori Pengetahuan & Jumlah & Presentase (\%) \\
\hline 1. & Baik & 15 & 75 \\
\hline 2. & Cukup & 5 & 25 \\
\hline 3. & Kurang & 0 & 0 \\
\hline \multicolumn{2}{|r|}{ Total } & 20 & $100 \%$ \\
\hline
\end{tabular}

Dari tabel 4.4 diatas dapat dilihat bahwa

Gambaran Pengetahuan Mahasiswa keperawatan tentang penularan infeksi nosokomial secara kontak langsung di RS PTPN II Bangkatan Binjai yang berpengetahuan Baik adalah sebanyak 15 orang $(75 \%)$, berpengetahuan cukup adalah sebanyak 5 orang $(25 \%)$, dan berpengetahuan kurang adalah sebanyak 0 orang $(0 \%)$. 
Tabel 4.5 Distribusi Frekuensi Mengenai Gambaran Pengetahuan Mahasiswa Keperawatan Tentang Penularan Infeksi Nosokomial Berdasarkan Penularan Infeksi Melalui Common Vehicle Di Rumah Sakit PTPN II Bangkatan Binjai Tahun 2017

\begin{tabular}{|c|c|c|c|}
\hline No & Kategori Pengetahuan & Jumlah & Presentase $(\%)$ \\
\hline 1. & Baik & 10 & 50 \\
\hline 2. & Cukup & 5 & 25 \\
\hline 3. & Kurang & 5 & 25 \\
\hline \multicolumn{2}{|r|}{ Total } & 20 & $100 \%$ \\
\hline
\end{tabular}

\section{Analisa Data:}

Dari tabel 4.5 diatas dapat dilihat bahwa Gambaran Pengetahuan Mahasiswa keperawatan tentang penularan infeksi nosokomial melalui common vehicle di RS PTPN II Bangkatan Binjai yang berpengetahuan Baik adalah sebanyak 10 orang (50\%), berpengetahuan Cukup adalah sebanyak 5 orang (25\%), dan berpengetahuan kurang adalah sebanyak 5 orang (25\%).

\section{PEMBAHASAN}

Dari hasil penelitian yang peneliti lakukan dapat diketahui bahwa dari 20 responden berdasarkan umur bahwa rata-rata umur mahasiswa keperawatan mayoritas usia berada pada usia 18-20 tahun sebanyak 10 orang (50\%), umur 21-22 tahun sebanyak 6 orang (30\%), umur 23-264 tahun sebanyak 3 orang (15\%), dan minoritas umur berusia 25-26 tahun sebanyak 1 orang (5\%).

Sedangkan berdasarkan dari hasil penelitian yang peneliti lakukan dapat diketahui bahwa dari 20 responden berdasarkan jenis kelamin bahwa rata-rata responden mayoritas berjenis kelamin perempuan sebanyak 12 orang $(60 \%)$ dan minoritas responden berjenis kelamin lakilaki sebanyak 8 orang (40\%).

Untuk hasil penelitian yang peneliti lakukan dapat diketahui bahwa dari 20 responden berdasarkan tingkat pendidikan bahwa seluruh responden berada di tingkat pendidikan D-III sebanyak 20 orang $(100 \%)$.

Selanjutnya berdasarkan dari hasil penelitian yang peneliti lakukan dapat diketahui bahwa tingkat pengetahuan mahasiswa keperawatan dari 20 responden berdasarkan gambaran pengetahuan mahasiswa keperawatan tentang penularan infeksi nosokomial secara kontak langsung di Rumah sakit PTPN II Bangkatan Binjai tahun 2017 mayoritas berpengetahuan baik sebanyak 15 orang $(75 \%)$, berpengetahuan cukup sebanyak 5 orang (15\%), dan berpengetahuan kurang sebanyak 0 orang $(0 \%)$.
Berdasarkan tingkat pengetahuan mahasiswa keperawatan dari 20 responden ternyata gambaran pengetahuan mahasiswa keperawatan tentang penularan infeksi nosokomial melalui common vehicle di Rumah sakit PTPN II Bangkatan Binjai tahun 2017 mayoritas berpengetahuan baik sebanyak 10 orang $(50 \%)$, berpengetahuan cukup sebanyak 5 orang (25\%), dan berpengetahuan kurang sebanyak 5 orang $(25 \%)$.

Sedangkan penularan infeksi nosokomial melalui udara dan inhalasi di Rumah sakit PTPN II Bangkatan Binjai tahun 2017 mayoritas berpengetahuan baik adalah sebanyak 14 orang (70\%), berpengetahuan cukup sebanyak 6 orang $(30 \%)$, dan berpengetahuan kurang sebanyak 0 orang $(0 \%)$.

Dan untuk penularan infeksi nosokomial melalui vektor di Rumah sakit PTPN II Bangkatan Binjai tahun 2017 mayoritas berpengetahuan baik adalah sebanyak 14 orang $(70 \%)$, berpengetahuan cukup sebanyak 5 orang (25\%), dan berpengetahuan kurang sebanyak 1 orang $(5 \%)$.

\section{KESIMPULAN}

Berdasarkan hasil penelitian dan pembahasan berdasarkan hasil pengukuran terhadap karakteristik responden dan jawaban quisioner tentang gambaran pengetahuan mahasiswa keperawatan tentang penularan infeksi nosokomial di rumah sakit PTPN II Bangkatan Binjai 
tahun 2017 maka, dapat disimpulkan bahwa:

1. Berdasarkan Umur, Peneliti dapat mengetahui bahwa dari 20 responden rata-rata umur mahasiswa keperawatan mayoritas berada pada usia 18-20 tahun sebanyak 10 orang $(50 \%)$, umur $21-22$ tahun sebanyak 6 orang (30\%), umur 2324 tahun sebanyak 3 orang (15\%), dan minoritas berada pada usia 25-25 tahun sebanyak 1 orang (5\%).

2. Berdasarkan Jenis Kelamin, Peneliti dapat mengetahui bahwa dari 20 responden berdasarkan jenis kelamin bahwa rata-rata responden yang berjenis kelamin laki-laki sebanyak 8 orang (40\%) dan responden yang berjenis kelamin perempuan sebanyak 12 orang $(60 \%)$.

3. Berdasarkan Tingkat Pendidikan, Peneliti dapat mengetahui bahwa dari 20 responden berdasarkan tingkat pendidikan bahwa seluruh responden berada di tingkat pendidikan D-III sebanyak 20 orang (100\%).

4. Berdasarkan hasil penelitian yang telah dilakukan peneliti maka dapat diketahui bahwa gambaran pengetahuan mahasiswa keperawatan tentang penularan infeksi nosokomial di rumah sakit PTPN II Bangkatan Binjai tahun 2017 mayoritas berpengetahuan baik tentang penularan infeksi secara kontak langsung sebanyak 15 orang (75\%), Penularan melalui common vehicle sebanyak 10 orang $(50 \%)$, Penularan melalui udara dan inhalasi sebanyak 14 orang $(70 \%)$, dan Penularan melalui vektor sebanyak 14 orang (70\%).

Jadi dapat diketahui bahwa pengetahuan mahasiswa mengenai penularan infeksi nosokomial mayoritas mahasiswa lebih memahami bahwa infeksi nosokomial dapat di tularkan secara kontak langsung dengan prevalensi 15 orang $(75 \%)$.

\section{SARAN}

Dari kesimpulan diatas maka peneliti dapat memberikan saran sebagai berikut:

1. Bagi dinas kesehatan kota Binjai diharapkan dapat lebih memperhatikan bahwa infeksi nosokomial masih merupakan salah satu hal yang mengancam kesehatan petugas kesehatan maupun pasien di rumah sakit. Untuk itu bagi dinas kesehatan kota Binjai diharapkan dapat memberikan pelatihan tentang pencegahan infeksi nosokomial untuk menurunkan angka infeksi di rumah sakit.

2. Bagi pihak rumah sakit dan tenaga kesehatan hendaknya dapat meningkatkan mutu kesehatan dengan membuat surveilans kesehatan yang lebih baik.

\section{DAFTAR PUSTAKA}

Bakhtiar, A. 2016. Filsafat Ilmu, Jakarta: Grafindo

Herlambang, S. 2014. Manajemen Kesehatan Rumah Sakit. Yogyakarta: Gosyen Publishing

Kusnanto. 2004. Pengantar Profesi \& Praktik Keperawatan Profesional. Jakarta: EGC.

Murwani dan Herlambang. 2012. Cara Mudah Memahami Manajemen Kesehatan dan Rumah Sakit. Yogyakarta: Gosyen Publishing.

Notoadmodjo, S. 2012. Metodologi Penelitian Kesehatan. Jakarta: Rineka Cipta

Pratama, M.Y. 2017. Pengaruh Motivasi Intrinsik Terhadap Kinerja Perawat Pelaksana di Rumah Sakit Tk. IV Pematang Siantar. Jurnal Ilmiah Penelitian Kesehatan, Volume 2, No. 1 (2017). Tanggal akses 5 Juni 2017.

Rifiani, N. 2013. Prinsip-prinsip Dasar Keperawatan. Jakarta:Dunia Cerdas

Septriari, B. 2015. Infeksi Nosokomial. Yogyakarta: Nuha Medika

Siregar, C. 2004. Farmasi Klinik Teori dan Penerapan. Jakarta. EGC

Tietjen, L. 2004. Panduan Pencegahan Infeksi. Jakarta: Bina Pustaka

Wawan. 2015. Teori Pengukuran Pengetahuan, Sikap, dan Perilaku.Yogya: Nuha Medika 